\title{
The pregnant women's experiences during the COVID-19 pandemic: a scoping review
}

\author{
Shelly Rodliah Rosyad ${ }^{\mathrm{a}, 1, *}$, Yekti Satriyandari ${ }^{\mathrm{b}, 2}$, Surabhi Sharma ${ }^{\mathrm{c}, 3}$ \\ ${ }^{a}$ Master of Midwifery, Faculty of Health Sciences, Universitas 'Aisyiyah Yogyakarta, Indonesia \\ ${ }^{b}$ Lecturer of Master of Midwifery Science, Faculty of Health Sciences, Universita 'Aisyiyah Yogyakarta, Indonesia \\ 'Independent Researcher, New Delhi, India \\ ${ }^{1}$ rosyad_shelly@yahoo.com*, ${ }^{2}$ yektisatriyandari@unisayogya.ac.id, ${ }^{3}$ Surabhi2210@gmail.com \\ *corresponding author
}

ARTICLE INFO

Article history

Received, $1^{\text {-st }}$ July 2021

Revised, 27-th November 2021

Accepted, 23-th October 2021

Keywords

Experiences

Pregnant women

COVID-19

\begin{abstract}
Backgrounds: Pregnancy is a normal physiological process experienced by women. During this COVID-19 pandemic, pregnant women have atypical experiences. The COVID-19 pandemic also instigates psychological problems in the form of anxiety and depression in pregnant women. Supports are exceedingly needed by pregnant women, especially during the current pandemic. They can take several measures during their pregnancy to reduce their level of anxiety.

Objective of the study: To review evidence related to pregnant women's experiences during the COVID-19 pandemic.

Review methods: This scoping review method begins with identifying scoping review questions using PEO framework; identifying relevant articles chosen based on inclusion and exclusion criteria; searching for articles using databases, namely EBSCO, PubMed, Science Direct, and Wiley Online Library; selecting articles of which search flow is described through PRISMA Flowchart; performing data charting and critical appraisal; and compiling and reporting results.

Results: Based on 8 chosen articles, 7 articles are marked grade A in quantitative research design non-randomized (5), quantitative descriptive (1), qualitative (1), and 1 article is marked grade B in quantitative descriptive research design. Furthermore, there are 3 obtained themes, including psychological conditions, coping strategies and the pregnant women's needs during the COVID-19 pandemic.

Conclusion: The COVID-19 pandemic affects the pregnant women's experiences due to the emergence of psychological responses in the form of anxiety, depression and fear. One of coping strategies carried out by pregnant women during the COVID-19 pandemic is by doing physical activities such as exercising, doing their hobbies, thinking positively and finding out information. Social supports and accurate information obtained help pregnant women to overcome their anxiety.
\end{abstract}

This is an open access article under the CC-BY-SA license.

\section{Introduction}

Pregnancy is a normal physiological process experienced by women. During this COVID-19 pandemic, pregnant women have different experiences. It is necessary to have an understanding of the pregnant women's experiences and perspectives in undergoing their pregnancy during the COVID-19 pandemic to find out their needs and expectations (Masjoudi et al., 2020). The COVID-19 pandemic 
has profoundly affected the pregnant women's mental health, driving changes in anxiety during their pregnancy (Moyer et al., 2020). Has stated that 53\% of respondents have high anxiety about vertical transmission of COVID-19 to their fetuses (Saccone, 2020). The psychological impacts and anxiety caused by COVID-19 are experienced more severely in pregnant women during their first trimester. Supports are needed by pregnant women, especially during pandemic. For pregnant women, social and emotional supports are vital. Pregnant women naturally want to talk about problems bothering them, as well as to choose the right person to share the said problems (Mlotshwa et al., 2017). The developments of support and intervention strategies for pregnant women during pandemic need to focus more on stress reduction and social support promotion (Olander \& Meaney, 2020). Pregnant women can take several measures during their pregnancy to reduce their level of anxiety. Strategies to overcome this problem are important to prevent the experiences that may cause stress-related mental disorders (N Kar et al., 2020). The purpose of this Scoping Review is to review evidence related to pregnant women's experiences during the COVID-19 pandemic.

\section{Methods}

The method used in this research is scoping review. According to (Arksey \& O'Malley, 2019), there are four objectives in conducting scoping review which include (1) examining the extent and nature of research activities, (2) determining the value of conducting a full systematic review, (3) summarizing and disseminatig the findings, and (4) identifying research gaps in the existing literature (Levac et al., 2017).

\subsection{Research question}

The problems in this study are examined through the previous research journal articles' results about pregnant women's experiences during the COVID-19 pandemic. Based on the phenomenon, the PEO framework is used to construct scoping review questions presented in table 1.

Table 1. PEO Framework

\begin{tabular}{ccc}
\hline (P) Population & (E) Exposure & (O) Outcome \\
\hline Pregnant women & COVID-19 pandemic & Anxiety symptoms \\
& & $\begin{array}{c}\text { Coping strategy } \\
\text { Support }\end{array}$ \\
\hline
\end{tabular}

\subsection{Search strategy design}

The databases used in the source searching process are EBSCO, PubMed, ScienceDirect, and Wiley Online Library. Source searching using EBSCO database and Wiley Online Library are accessed through Unisa Library, PubMed is accessed via Google, and Science Direct is accessed from PNRI. The article searching strategy is carried out by entering keywords in the searching process using Medical Subject Headings (MeSH) and truncation / wildcard symbols and boolean operators strategy including "Pregnant* OR Prenatal OR Antenatal AND COVID-19 OR Coronavirus OR Pandemic OR Covid19 OR SARS-CoV-2 AND Experience* OR View* OR Perspective* AND Anxiet* OR Stress* OR Depression* OR Fear* AND Coping strategy* OR Coping Mechanism* AND Support". The inclusion criteria in this study are articles published from 2019 to 2020, in English or Indonesian, discussing the experiences of pregnant women during the COVID-19 pandemic. Exclusion criteria in this study are opinion articles, review articles, commentaries and book reviews. Screening is conducted to select articles that fall into the inclusion criteria by reading articles based on title, abstract, and full-text. 


\section{Results}

There are 53 articles obtained from searches in the database. 10 duplicate articles are then removed, leaving 43 articles. Subsequently, articles are eliminated based on the title and abstract resulting in the exclusion of 34 articles because they are not relevant, leaving 9 relevant articles. Then, full textreading on the articles are conducted, resulting in the exclusion of 1 article due to errors in the population. So there are 8 articles chosen for scoping review. The selection article is presednted in a flow diagram in Fig. 1.

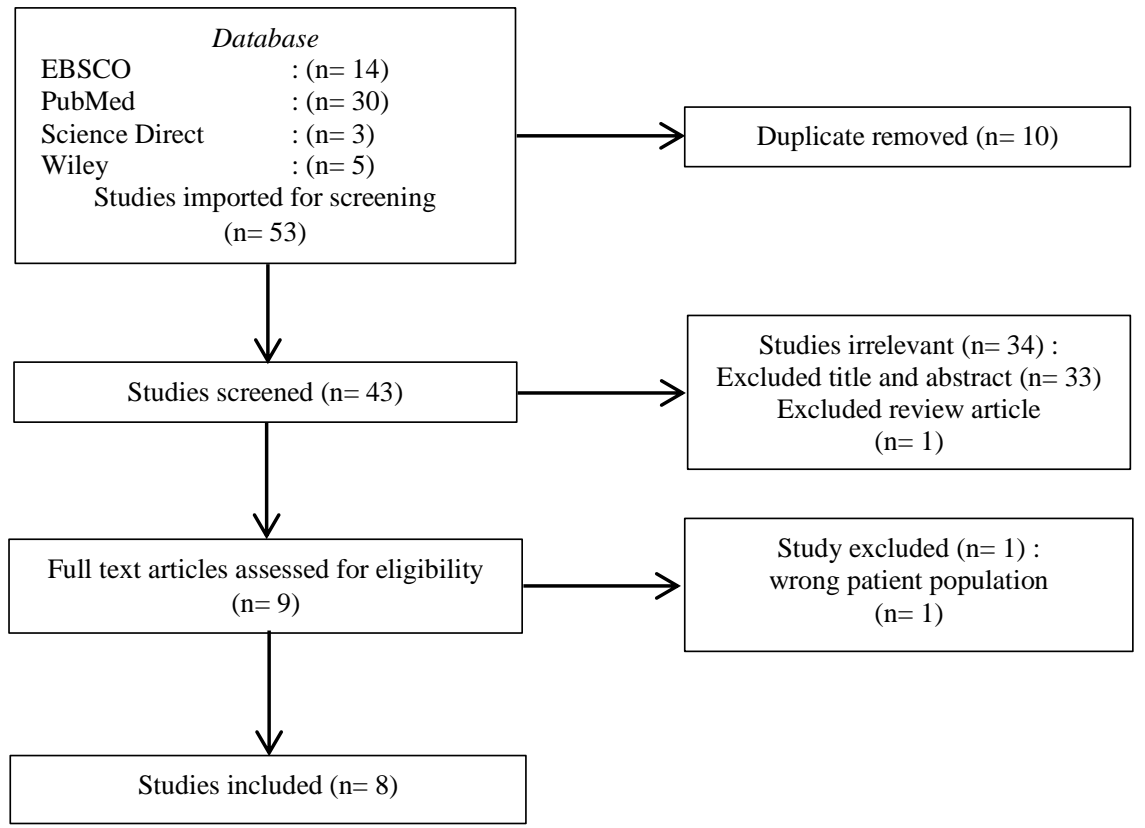

Fig. 1. PRISMA Flowchart

After finding 8 relevant articles, the author synthesizes the findings into data extraction table. Data extraction is made in the form of table containing author's name, year, title, grade, country, aim, type of research, data collection, participants/sample size and result. The synthesis of findings is presented in table 2 . 
Table 2. Data Extraction

\begin{tabular}{|c|c|c|c|c|c|c|c|}
\hline No. & $\begin{array}{c}\text { Author/ Year/Title/ } \\
\text { Grade }\end{array}$ & Country & Aim & $\begin{array}{c}\text { Type of } \\
\text { Research }\end{array}$ & Data Collection & $\begin{array}{l}\text { Participants/ } \\
\text { Sample Size }\end{array}$ & Result \\
\hline A1 & $\begin{array}{l}\text { (Salehi et al., 2020) / The } \\
\text { relationship of fear and } \\
\text { anxiety of COVID-19, } \\
\text { pregnancy experience, } \\
\text { and mental health } \\
\text { disorder in pregnant } \\
\text { women: A structural } \\
\text { equation model/ A }\end{array}$ & Iran & $\begin{array}{l}\text { To assess pregnant women's } \\
\text { fear and anxiety against } \\
\text { COVID-19, and their } \\
\text { pregnancy experiences and } \\
\text { mental health. }\end{array}$ & $\begin{array}{l}\text { Quantitative non- } \\
\text { randomized study }\end{array}$ & $\begin{array}{l}\text { Data collection is } \\
\text { conducted using } \\
\text { questionnaires. }\end{array}$ & $\begin{array}{l}\text { Sample size : } 222 \\
\text { pregnant women who } \\
\text { are referred to Kamali } \\
\text { Hospitalian in Alborz } \\
\text { province. }\end{array}$ & $\begin{array}{c}\text { Obtained themes: } \\
\text { Psychological state: } \\
\text { there is anxiety directly related to } \\
\text { COVID-19 and fear indirectly caused } \\
\text { by COVID-19 which may affect } \\
\text { pregnant women's mental health. }\end{array}$ \\
\hline A2 & $\begin{array}{c}\text { (Lebel et al., 2020b) / } \\
\text { Elevated depression and } \\
\text { anxiety symptoms among } \\
\text { pregnant individuals } \\
\text { during the COVID-19 } \\
\text { pandemic/ B }\end{array}$ & Canada & $\begin{array}{l}\text { To determine the prevalence } \\
\text { of pregnant women's anxiety } \\
\text { and depression symptoms } \\
\text { during the COVID-19 } \\
\text { pandemic and identify } \\
\text { resilience factors associated } \\
\text { with psychological distress }\end{array}$ & $\begin{array}{c}\text { Quantitative } \\
\text { descriptive study }\end{array}$ & $\begin{array}{l}\text { Data collection is } \\
\text { conducted using } \\
\text { questionnaires. }\end{array}$ & $\begin{array}{c}\text { Participants : } 1987 \\
\text { pregnant women in } \\
\text { Canada }\end{array}$ & $\begin{array}{c}\text { Obtained themes: } \\
\text { Psychological state: } \\
\text { depression, generalized anxiety and } \\
\text { pregnancy anxiety symptoms are } \\
\text { higher among pregnant women with } \\
\text { similar demographic profiles and there } \\
\text { are concerns that the virus will } \\
\text { adversely affect the fetus. } \\
\text { Pregnant women's needs: } \\
\text { Anxiety and depression symptoms are } \\
\text { lower if participants get social } \\
\text { supports from their partners or from } \\
\text { general social supports. } \\
\text { Resilience factors: } \\
\text { Doing exercises and physical activities }\end{array}$ \\
\hline A3 & $\begin{array}{l}\text { (Mappa et al., 2020a)/ } \\
\text { Effects of coronavirus } 19 \\
\text { pandemic on maternal } \\
\text { anxiety during pregnancy: } \\
\text { a prospective } \\
\text { observational study/ A }\end{array}$ & Italy & $\begin{array}{l}\text { To evaluate the psychological } \\
\text { impact of the COVID-19 } \\
\text { pandemic on pregnant women } \\
\text { in Italy }\end{array}$ & $\begin{array}{c}\text { Quantitative } \\
\text { descriptive study }\end{array}$ & $\begin{array}{c}\text { Data collection is } \\
\text { carried out using a } \\
\text { semi-structured online } \\
\text { questionnaire sent via } \\
\text { email }\end{array}$ & $\begin{array}{l}\text { Participants: } 200 \\
\text { pregnant women }\end{array}$ & $\begin{array}{c}\text { Obtained themes: } \\
\text { Psychological conditions: } \\
\text { Pregnant women are worried that } \\
\text { COVID-19 can induce fetal structural } \\
\text { anomalies, impair fetal growth, and } \\
\text { cause premature labors. The pregnant } \\
\text { women's anxiety is at abnormal level. } \\
\text { Pregnant women's needs: } \\
\text { information regarding the effect of } \\
\text { COVID-19 on pregnancy. }\end{array}$ \\
\hline
\end{tabular}




\begin{tabular}{|c|c|c|c|c|c|c|c|}
\hline A4 & $\begin{array}{c}\text { (Ayaz et al., 2020a)/ } \\
\text { Anxiety and depression } \\
\text { symptoms in the same } \\
\text { pregnant women before } \\
\text { and during the COVID-19 } \\
\text { pandemic/ A }\end{array}$ & Turkey & $\begin{array}{c}\text { To compare the levels of } \\
\text { anxiety and depression in the } \\
\text { same pregnant women before } \\
\text { and during the COVID-19 } \\
\text { pandemic }\end{array}$ & $\begin{array}{l}\text { Quantitative non- } \\
\text { randomized study }\end{array}$ & $\begin{array}{l}\text { Data collection is } \\
\text { conducted using } \\
\text { questionnaires. }\end{array}$ & $\begin{array}{l}\text { Participants: } 200 \\
\text { pregnant women }\end{array}$ & $\begin{array}{c}\text { Obtained themes: } \\
\text { Psychological conditions: } \\
\text { Compared to before the pandemic, } \\
\text { depression and anxiety symptoms } \\
\text { significantly increase during the } \\
\text { SARS-CoV-2 pandemic. }\end{array}$ \\
\hline A5 & $\begin{array}{c}\text { (Kahyaoglu \& } \\
\text { Kucukkaya, 2020)/ } \\
\text { Anxiety, depression, and } \\
\text { related factors in pregnant } \\
\text { women during the } \\
\text { COVID-19 pandemic in } \\
\text { Turkey: A web-based } \\
\text { cross-sectional study/ A }\end{array}$ & Turkey & $\begin{array}{l}\text { To examine the prevalence of } \\
\text { anxiety and depression levels } \\
\text { and factors associated with } \\
\text { pregnant women during the } \\
\text { COVID-19 pandemic }\end{array}$ & $\begin{array}{l}\text { Quantitative non- } \\
\text { randomized study }\end{array}$ & $\begin{array}{l}\text { Data collection is } \\
\text { carried out using an } \\
\text { online web-based } \\
\text { survey. }\end{array}$ & $\begin{array}{c}\text { Participants : } 403 \\
\text { pregnant women over } \\
18 \text { years old }\end{array}$ & $\begin{array}{l}\text { Obtained themes: } \\
\text { Psychological conditions: } \\
\text { The prevalence of anxiety and } \\
\text { depression in pregnant women during } \\
\text { the COVID-19 pandemic are } 64.5 \% \\
\text { and } 56.3 \% \text {, respectively. } \\
\text { Pregnant women's needs: information } \\
\text { on the effects of COVID-19 on } \\
\text { pregnancy. }\end{array}$ \\
\hline A6 & $\begin{array}{l}\text { (Sahin \& Kabakci, 2020)/ } \\
\text { The experiences of } \\
\text { pregnant women during } \\
\text { the COVID-19 pandemic } \\
\text { in Turkey: A qualitative } \\
\text { study/ A }\end{array}$ & Turkey & $\begin{array}{l}\text { To find out pregnant women's } \\
\text { experiences during the } \\
\text { COVID-19 pandemic }\end{array}$ & Qualitative study & $\begin{array}{l}\text { Data is collected } \\
\text { using semi-structured } \\
\text { questionnaire } \\
\text { questions. }\end{array}$ & $\begin{array}{l}\text { Participants: } 15 \\
\text { pregnant women }\end{array}$ & $\begin{array}{c}\text { Obtained themes: } \\
\text { Psychological conditions: } \\
\text { Pregnant women are worried and } \\
\text { anxious because they are pregnant } \\
\text { during pandemic. } \\
\text { Coping strategies: } \\
\text { doing different hobbies at home, } \\
\text { focusing on the silver lining, not } \\
\text { watching the latest news related to } \\
\text { COVID-19. } \\
\text { Pregnant women's needs: } \\
\text { Getting information about COVID-19 } \\
\text { and supports from health workers } \\
\text { make pregnant women feel more } \\
\text { comfortable. }\end{array}$ \\
\hline
\end{tabular}




\begin{tabular}{|c|c|c|c|c|c|c|c|}
\hline A7 & $\begin{array}{l}\text { (Farrel, Reagu, Mohan, } \\
\text { Elmidany, Qaddoura, \& } \\
\text { Ahmed, 2020) / The } \\
\text { impact of the COVID-19 } \\
\text { pandemic on the perinatal } \\
\text { mental health of women/ } \\
\text { A }\end{array}$ & Qatar & $\begin{array}{l}\text { To study the impact of the } \\
\text { COVID-19 pandemic and } \\
\text { restrictions on women's } \\
\text { perinatal mental health in } \\
\text { Qatar }\end{array}$ & $\begin{array}{l}\text { Quantitative non- } \\
\text { randomized study }\end{array}$ & $\begin{array}{l}\text { Data collection is } \\
\text { conducted using } \\
\text { questionnaires. }\end{array}$ & $\begin{array}{c}\text { Sample size : } 288 \\
\text { pregnant women }\end{array}$ & $\begin{array}{c}\text { Obtained themes: } \\
\text { Psychological conditions: } \\
\text { Pregnant women experience anxiety } \\
\text { and depression during the COVID-19 } \\
\text { pandemic. } \\
\text { Coping strategies: } \\
\text { seeking information related to the } \\
\text { pandemic and taking preventive } \\
\text { measures during pregnancy through } \\
\text { medical workers and public health } \\
\text { information broadcasts on television, } \\
\text { as well as doing physical activities } \\
\text { such as exercising as a coping } \\
\text { mechanism. }\end{array}$ \\
\hline A8 & $\begin{array}{l}\text { (Berthelot et al., 2020a)/ } \\
\text { Uptrend in distress and } \\
\text { psychiatric } \\
\text { symptomatology in } \\
\text { pregnant women during } \\
\text { the coronavirus disease } \\
2019 \text { pandemic/ A }\end{array}$ & Canada & $\begin{array}{l}\text { To determine the breadth of } \\
\text { the COVID-19 pandemic } \\
\text { influence on the increase of } \\
\text { prenatal psychological stress } \\
\text { in pregnant women }\end{array}$ & $\begin{array}{l}\text { Quantitative non- } \\
\text { randomized study }\end{array}$ & $\begin{array}{l}\text { Data is collected } \\
\text { using a cohort }\end{array}$ & $\begin{array}{c}\text { Sample size }: 1,754 \\
\text { pregnant women }\end{array}$ & $\begin{array}{c}\text { Obtained themes: } \\
\text { Psychological conditions: } \\
\text { Pregnant women in particular may } \\
\text { experience symptoms of anxiety and } \\
\text { depression during the COVID-19 } \\
\text { pandemic. }\end{array}$ \\
\hline
\end{tabular}




\section{Findings}

\subsection{Article Characteristics}

Based on the study design of the 8 articles selected, 5 articles use non-randomized quantitative studies, 2 articles use quantitative descriptive studies and 1 article use qualitative studies.

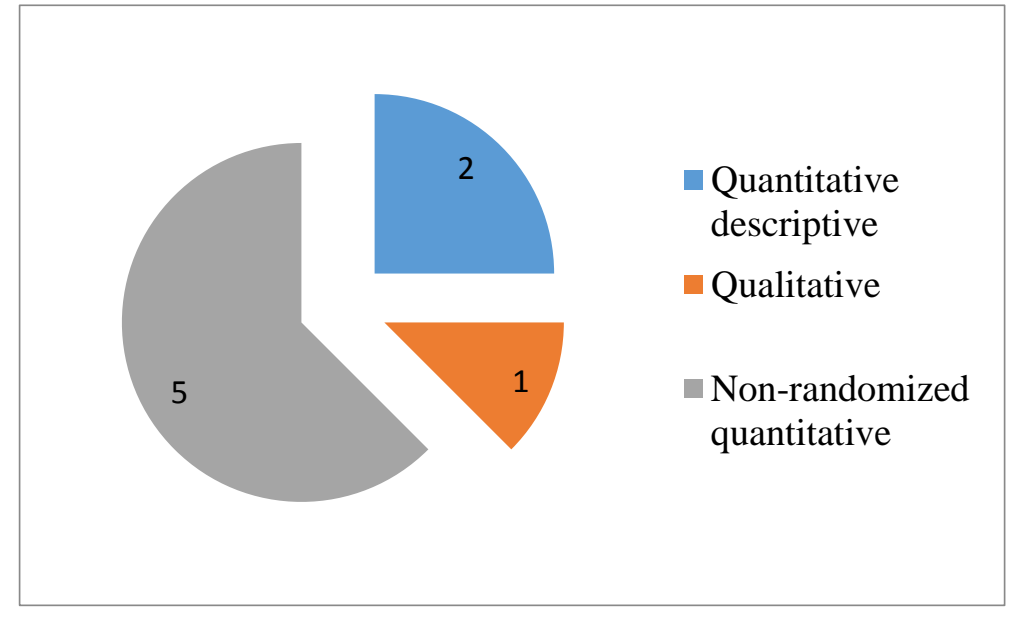

Fig. 2. Article based on study design

Based on the quality used Mixed Method Appraisal Tool (MMAT) as a tool to determine the quality of the selected articles, there are 7 articles marked grade A, 1 article marked grade B and there is no article marked grade $\mathrm{C}$.

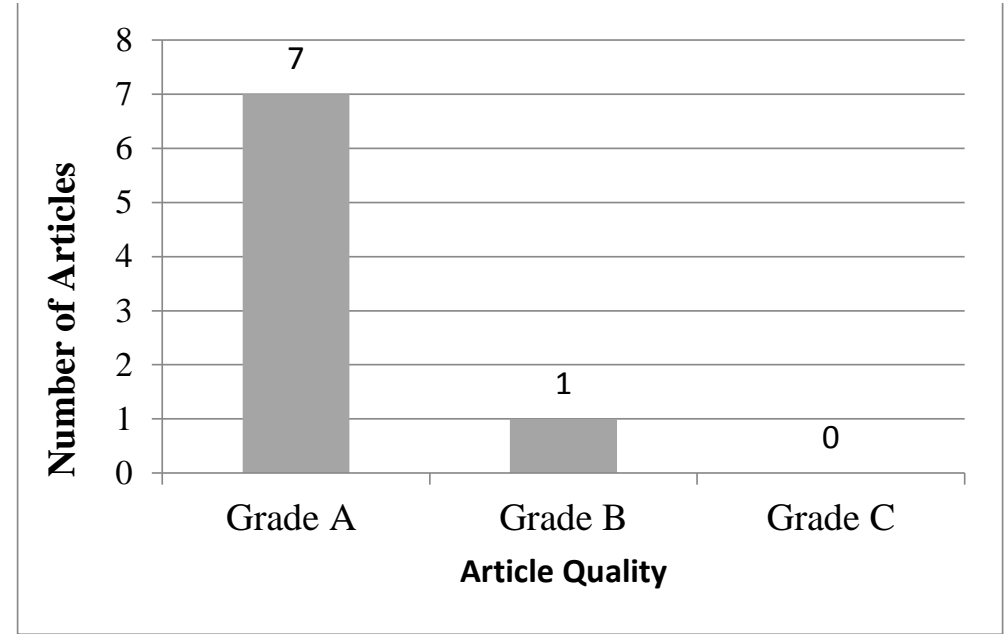

Fig. 3. Articles based on quality

Based on the countries, there are studies conducted in developing countries such as Iran, Turkey and Qatar. There are also researches conducted in developed countries such as Canada and Italy. 


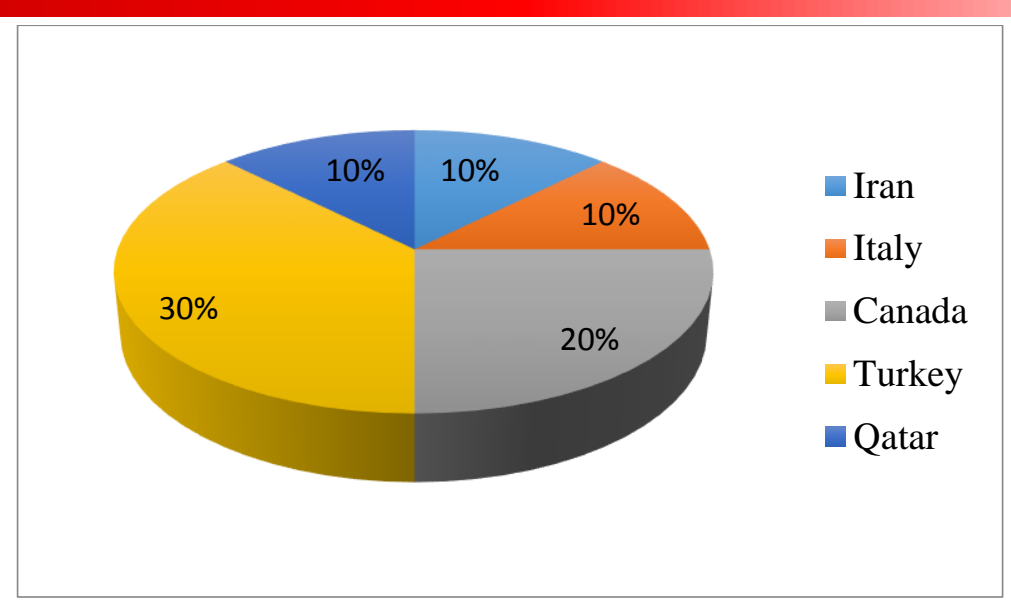

Fig. 4. Articles based on countries

\subsection{Theme Mapping}

The next stage is to map the themes based on the selected articles. There are 3 obtained themes which include the pregnant women's psychological conditions, coping strategies, and the pregnant women's needs during the COVID-19 pandemic.

\section{Discussion}

\subsection{Pregnant Women's Psychological Condition during the COVID-19 Pandemic}

a) Anxiety

Anxiety affects pregnant women during pandemic. Anxiety experienced during pregnancy is about the health of the fetus (Peã'A coba-Puente et al., 2011). During the COVID-19 pandemic, pregnant women show increased anxiety(Ayaz et al., 2020b; Berthelot et al., 2020b; Farrel, Reagu, Mohan, Elmidany, Qaddoura, Ahmed, et al., 2020; Mappa et al., 2020b). Anxiety experienced here is related to their, their babies', and their family's health (Mizrak Sahin \& Kabakci, 2020). The greatest effect of these anxiety symptoms is caused by social isolation (Lebel et al., 2020a). Social isolation can be in the form of contact reduction with other people, interaction frequency reduction with others, inability to depend on family, friends or partners, isolated and excluded feelings (Coplan \& Bowker, 2015). Anxiety experienced by pregnant women is significantly higher in those who have low education level, do not have a job, do not do any physical activities and do not receive any information from doctors/nurses/midwives about the effects of COVID-19 on pregnancy (Kahyaoglu \& Kucukkaya, 2020).

\section{b) Depression}

The pressure felt by pregnant women during the COVID-19 pandemic can trigger depression symptoms on them. Pregnant women show aggravated symptoms of depression during the COVID-19 pandemic (Berthelot et al., 2020b; Farrel, Reagu, Mohan, Elmidany, Qaddoura, \& Ahmed, 2020). Depression is harmful. Depression during pregnancy is associated with adverse pregnancy outcomes for both mother and baby (Mesches et al., 2015). The clinically intensified depression symptoms are caused by pregnant women's anxiety regarding COVID-19 which later can threaten their lives, endanger their babies, render them unable to get the necessary care, feel isolated, and strain their relationships with their partners (Lebel et al., 2020b). Depression is significantly higher in pregnant women of which education level is below junior high school level, do not do any physical activities, is reluctant to visit hospital or doctor for pregnancy visits and have no knowledge on the effects of COVID-19 on pregnancy (Kahyaoglu \& Kucukkaya, 2020).

\section{c) Fear}

Fear is an aspect of life and is often explored as a temporary emotional state that is based on different elements for each person (Hatemi et al., 2018). The COVID-19 pandemic has created 
fear and anxiety around the world(Singh et al., 2020). Fear of the corona virus during pregnancy indirectly affects pregnant women's mental health during their pregnancy (Salehi et al., 2020). The fear experienced by pregnant women during the COVID-19 pandemic is in the form of fear of abnormal perinatal outcomes that can induce fetal structural anomalies, fetal growth restriction and preterm labor (Mappa et al., 2020b). However, the main reason for the abovementioned fear is due to their pregnancy during the COVID-19 pandemic (Mizrak Sahin \& Kabakci, 2020).

\subsection{Pregnant Women's Coping Strategies during the COVID-19 Pandemic \\ a) Physical activities}

Physical activities are an effective strategy to overcome negative psychological effects of the COVID-19 pandemic (Violant-Holz et al., 2020). One of physical activities that can be done is exercising. Exercising as a coping mechanism in times of stress is beneficial (Garber, 2017). Exercise is a form of physical activity that can be used as a coping mechanism carried out by pregnant women to relieve stress during the COVID-19 pandemic (Farrel, Reagu, Mohan, Elmidany, Qaddoura, \& Ahmed, 2020).

\section{b) Hobbies and positive thinking}

One of the coping mechanisms carried out by pregnant women during the COVID-19 pandemic is by doing activities or hobbies such as reading books, focusing on the silver lining by praying to overcome anxiety and worries during the pandemic and not watching the latest news to avoid anxiety due to the pandemic (Sahin \& Kabakci, 2020). These activities are proven useful. Coping mechanisms that can be done is by sharing emotions, doing activities, not overthinking (Nilamadhab Kar et al., 2020).

\section{c) Information searching}

The information obtained will be useful to reduce anxiety and fear. Using the available information on how to solve a problem and an effective problem solving strategy will be very useful (Vaira et al., 2020). Coping mechanisms that can be done by pregnant women are by seeking information through maternity staffs and health information on television related to the pandemic. There are preventive measures that need to be taken by pregnant women during the pandemic..

\subsection{Pregnant Women's Needs During the COVID-19 Pandemic a) Information}

During the pandemic, pregnant women get the information related to COVID-19 through journals, television, and websites. Pregnant women can always communicate with their midwives online without having to come to the service center. For pregnant women who are unable to do prenatal check-ups to get information from a doctor, midwife or nurse regarding COVID-19, information sources from the internet and television are indispensable.. During this COVID-19 pandemic, sufficient information is necessary in dealing with the current situation. Pregnant women who do not have sufficient information about the effects of COVID-19 on pregnancy may suffer from increased risk of anxiety and depression.

\section{b) Supports}

Support is needed to overcome the psychological problems experienced by pregnant women during the COVID-19 pandemic. The social support that pregnant women get during the COVID19 pandemic is a way to overcome depression and anxiety, especially because they have new responsibilities and roles. Due to the large number of people who have anxiety, depression, and stress symptoms related to COVID-19, a mental health support system is needed to be able to overcome these problems. Social supports as an emotional coping mechanism have the potential to affect someone's life quality (Shishehgar et al., 2013). Social supports can take the form of practical assistance in terms of routine activities, providing information or advice, emotional supports obtained from mothers, mother-in-laws, brothers and sister-in-laws, and husbands (Edmonds et al., 2014). Support can be obtained from family, friends, and social networks. Midwives as medical workers play an important role in providing support to pregnant women. Midwives are an important source of information for pregnant women (Grimes et al., 2014). 
During the COVID-19 pandemic, pregnant women, who can be easily contacted, receive support from doctors, midwives or nurses by telephone or online, thus making them feel more comfortable.

\section{Conclusion}

The COVID-19 pandemic affects the experiences undegone by pregnant women during their pregnancy with the emergence of psychological responses in the form of anxiety, depression and fear. One of coping strategies carried out by pregnant women during the COVID-19 pandemic is by doing physical activities such as exercising, doing their hobbies, thinking positively and finding out information. The social supports and accurate information obtained help pregnant women to overcome their anxiety. There is a gap found among the review results stating that the research results from developed countries tend to examine the pregnant women's psychological conditions and needs during the COVID-19 pandemic. Meanwhile, the research results in developing countries focus not only on examining the pregnant women's psychological conditions and needs during the COVID-19 pandemic but also on examining their coping strategies. This research then focuses on 5 articles researching developing countries and 3 articles researching developed countries. Further researches are later needed to examine the pregnant women's experiences during the COVID-19 pandemic in developed countries.

\section{Acknowledgment}

The author would like to thank Master of Midwifery Program, University of 'Aisyiyah Yogyakarta, who provides the facilities to conduct this study.

\section{References}

Arksey, \& O’Malley. (2019). Scoping studies: Towards a methodological framework. 8(1), 19-32.

Ayaz, Hocaoğlu, Günay, Yardlmcl, Turgut, \& Karateke. (2020a). Anxiety and depression symptoms in the same pregnant women before and during the COVID-19 pandemic. Journal of Perinatal Medicine, 48(9), 965-970. https://doi.org/10.1515/jpm-2020-0380

Ayaz, R., Hocaoğlu, M., Günay, T., Yardlmcl, O. D., Turgut, A., \& Karateke, A. (2020b). Anxiety and depression symptoms in the same pregnant women before and during the COVID-19 pandemic. Journal of Perinatal Medicine, 48(9), 965-970. https://doi.org/10.1515/jpm-20200380

Berthelot, Lemieux, Garon-Bissonnette, Drouin-Maziade, Martel, \& Maziade. (2020a). Uptrend in distress and psychiatric symptomatology in pregnant women during the coronavirus disease 2019 pandemic. Acta Obstetricia et Gynecologica Scandinavica, 99(7), 848-855. https://doi.org/10.1111/aogs.13925

Berthelot, N., Lemieux, R., Garon-Bissonnette, J., Drouin-Maziade, C., Martel, É., \& Maziade, M. (2020b). Uptrend in distress and psychiatric symptomatology in pregnant women during the coronavirus disease 2019 pandemic. Acta Obstetricia et Gynecologica Scandinavica, 99(7), 848-855. https://doi.org/10.1111/aogs.13925

Coplan, \& Bowker. (2015). The Handbook of Solitude: Psychological Perspective on Social Isolation, Social Withdrawal and Being Alone. In Wiley Blackwell.

Edmonds, Paul, \& Sibley. (2014). Type, content, and source of social support perceived by women during pregnancy: Evidence from Matlab, Bangladesh. Journal of Health, Population and Nutrition, 29(2), 163-173. https://doi.org/10.3329/jhpn.v29i2.7859

Farrel, Reagu, Mohan, Elmidany, Qaddoura, \& Ahmed. (2020). The Impact of the COVID-19 Perinatal Mental Health of Women. Deutsches Arzteblatt International, 117(50), 861-867. https://doi.org/10.3238/arztebl.2020.0861 
Farrel, T., Reagu, S., Mohan, S., Elmidany, R., Qaddoura, F., Ahmed, E. E. A., Lindow, S., Abuyaqoub, S. M., \& Alabdulla, M. A. (2020). The Impact of the COVID-19 Perinatal Mental Health of Women. Deutsches Arzteblatt International, 117(50), 861-867. https://doi.org/10.3238/arztebl.2020.0861

Garber. (2017). Exercise as a stress coping mechanism in a pharmacy student population. American Journal of Pharmaceutical Education, 81(3), 1-6. https://doi.org/10.5688/ajpe81350

Grimes, Forster, \& Newton. (2014). Sources of information used by women during pregnancy to meet their information needs. Midwifery, 30(1), 26-33. https://doi.org/10.1016/j.midw.2013.10.007

Hatemi, Mcdermott, Kendler, \& Neale. (2018). Fear as a Disposition and an Emotional State: A Genetic and Environmental Approach to Out-Group Political Preferences. American Journal of Political Science, 57(2), 279-293. https://doi.org/10.1111/ajps.12016

Kahyaoglu, \& Kucukkaya. (2020). Anxiety, depression, and related factors in pregnant women during the COVID-19 pandemic in Turkey: A web-based cross-sectional study. In Perspectives in Psychiatric Care, September. https://doi.org/10.1111/ppc.12627

Kar, N, Kar, B., \& Kar, S. (2020). Stress and coping during COVID-19 pandemic: Result of an online survey. January.

Kar, Nilamadhab, Kar, B., \& Kar, S. (2020). Stress and coping during COVID-19 pandemic: Result of an online survey. January.

Lebel, C., MacKinnon, A., Bagshawe, M., Tomfohr-Madsen, L., \& Giesbrecht, G. (2020a). Elevated depression and anxiety symptoms among pregnant individuals during the COVID-19 pandemic. Journal of Affective Disorders, 277(January), 5-13. https://doi.org/10.1016/j.jad.2020.07.126

Lebel, MacKinnon, Bagshawe, Tomfohr-Madsen, \& Giesbrecht. (2020b). Elevated depression and anxiety symptoms among pregnant individuals during the COVID-19 pandemic. Journal of Affective Disorders, 277(1), 5-13. https://doi.org/10.1016/j.jad.2020.07.126

Levac, Colquhoun, \& O’Brien. (2017). Scoping studies : advancing the methodology. Representing and Intervening, 1(1), 1-8. https://doi.org/10.1017/cbo9780511814563.003

Mappa, Distefano, \& Rizzo. (2020a). Effects of coronavirus 19 pandemic on maternal anxiety during pregnancy: a prospectic observational study. Journal of Perinatal Medicine, 48(6), 545-550. https://doi.org/10.1515/jpm-2020-0182

Mappa, I., Distefano, F. A., \& Rizzo, G. (2020b). Effects of coronavirus 19 pandemic on maternal anxiety during pregnancy: a prospectic observational study. Journal of Perinatal Medicine, 48(6), 545-550. https://doi.org/10.1515/jpm-2020-0182

Masjoudi, Aslani, Khazaeian, \& Fathnezhad-Kazemi. (2020). Explaining the experience of prenatal care and investigating the association between psychological factors with self-care in pregnant women during COVID-19 pandemic: A mixed method study protocol. Reproductive Health, 17(1), 1-7. https://doi.org/10.1186/s12978-020-00949-0

Mesches, Wisner, \& Betcher. (2015). Depression in Pregnant Women. Jama, 293(24), 2992. https://doi.org/10.1001/jama.293.24.2992-c

Mizrak Sahin, B., \& Kabakci, E. N. (2020). The experiences of pregnant women during the COVID19 pandemic in Turkey: A qualitative study. Women and Birth, December 2019. https://doi.org/10.1016/j.wombi.2020.09.022

Mlotshwa, Manderson, \& Merten. (2017). Personal support and expressions of care for pregnant women in Soweto, South Africa. Global Health Action, 10(1). https://doi.org/10.1080/16549716.2017.1363454 
Moyer, Compton, Kaselitz, \& Muzik. (2020). Pregnancy-related anxiety during COVID-19: a nationwide survey of 2740 pregnant women. In Archives of Women's Mental Health. https://doi.org/10.1007/s00737-020-01073-5

Olander, \& Meaney. (2020). Differences in levels of stress, social support, health behaviours, and stress-reduction strategies for women pregnant before and during the COVID-19 pandemic, and based on phases of pandemic restrictions, in Ireland.

Peã’Acoba-Puente, C., Monge, F. J. C., \& Morales, D. M. (2011). Pregnancy worries: A longitudinal study of Spanish women. Acta Obstetricia et Gynecologica Scandinavica, 90(9), 1030-1035. https://doi.org/10.1111/j.1600-0412.2011.01208.x

Saccone. (2020). Psychological impact of coronavirus disease 2019 in pregnant women. In American Journal of Obstetrics \& Gynecology. https://www.ncbi.nlm.nih.gov/pmc/articles/PMC7204688

Sahin, M., \& Kabakci. (2020). The experiences of pregnant women during the COVID-19 pandemic in Turkey: A qualitative study. In Women and Birth. https://doi.org/10.1016/j.wombi.2020.09.022

Salehi, Rahimzadeh, Molaei, Zaheri, \& Esmaelzadeh-Saeieh. (2020). The relationship among fear and anxiety of COVID-19, pregnancy experience, and mental health disorder in pregnant women: A structural equation model. Brain and Behavior, 10(11), 1-8. https://doi.org/10.1002/brb3.1835

Shishehgar, S., Mahmoodi, A., Dolatian, M., Mahmoodi, Z., Bakhtiary, M., \& Majd, H. A. (2013). The relationship of social support and quality of life with the level of stress in pregnant women using the PATH model. Iranian Red Crescent Medical Journal, 15(7), 560-565. https://doi.org/10.5812/ircmj.12174

Singh, Roy, Sinha, Parveen, Sharma, \& Joshi. (2020). Since January 2020 Elsevier has created a COVID-19 resource centre with free information in English and Mandarin on the novel coronavirus COVID- 19. The COVID-19 resource centre. In Psychiatry Research.

Vaira, Yanti, \& Hidayat. (2020). A qualitative study of partnership between woman and midwife within midwife-led care clinic. Journal of Health Technology Assessment in Midwifery, 3(1), 29-45. https://doi.org/10.31101/jhtam.1368

Violant-Holz, V., Gallego-Jiménez, M. G., González-González, C. S., Muñoz-Violant, S., Rodríguez, M. J., Sansano-Nadal, O., \& Guerra-Balic, M. (2020). Psychological health and physical activity levels during the covid-19 pandemic: A systematic review. International Journal of Environmental Research and Public Health, 17(24), 1-19. https://doi.org/10.3390/ijerph17249419 